\title{
THE EFFECTS OF HEALTH EDUCATION TO THE KNOWLEDGE LEVEL AND ATTITUDE OF ADOLESCENTS’ REPRODUCTIVE HEALTH
}

\author{
Saurmian Sinaga, Viktor Josse, Lidya Natalia \\ STIKes Immanuel, Bandung, Indonesia \\ Correspondence: mianstwin@yahoo.com
}

\begin{abstract}
Reproductive health is a healthy state physically, mentally, and socially intact, not solely free from diseases or disabilities related to reproductive systems, functions, and processes. Health education is the process of improving people's ability to maintain and improve their health. The purpose of this study was to determine the effect of health education on the level of knowledge and attitudes of adolescents about reproductive health in class VIII Madrasah Tsanawiyah Baabussalaam Bandung. The design of this research was the Pre-Experimental Designs with One-Group Pretest-Posttest Design, the sampling technique used the total sampling with 91 respondents. The result of the research showed that before health education, a small part of all respondents $(37,4 \%)$ have enough knowledge after given health education most of all respondents $(73 \%)$ have good knowledge about reproductive health. Prior to being given health education some of the respondents $(57.1 \%)$ had negative attitudes, after being given health education most of all respondents $(65.9 \%)$ had a positive attitude about reproductive health. The result of the Wilcoxon test analysis for the knowledge and attitude variables were significant (P-Value $0.000 \leq$ $0,05)$. It can be concluded that there is an influence of health education to the level of knowledge and attitude of adolescent about reproduction health in class VIII Madrasah Tsanawiyah Baabussalaam city of Bandung. Nurses are expected to maximize their role as an educator in providing health education for adolescents, especially on adolescent reproductive health.
\end{abstract}

Keywords: Knowledge, Attitude, Reproductive Health

\section{INTRODUCTION}

Adolescence is the moving period of individuals from child to adult phase (Bobak, Lowdermilk, \& Jensen, 2012). Adolescence is part of the child's growth cycle from the moment of conception to adulthood. Adolescence is a dynamic phase of development in an individual's life. Adolescence is a period of transition characterized by accelerated physical, mental, emotional and social development. These changes would affect the attitudes and behaviors of adolescents and cause problems (Nancy, 2010) in (Prajati, 2014).

The United Nations Population Fund (UNFPA) in 2005 estimated that 1.8 billion or $27 \%$ of the world's population was age ranged 10-24 years old, and 850 million of them in the Asia Pacific. Central Bureau of Statistics (2010) stated the number of adolescents (15-24 years) in Indonesia has increased to 3,457,591 people. While the youth population of Bandung, aged 10-24 years, was $28.55 \%$ of the total population, which is about 665,252 people (BPS, 2011). The number consists of 345,975 males and 319,277 females. 
Government Regulation No. 61 Chapter I, Article 1, Paragraph (2) in the Year 2014, on reproductive Health defined reproductive health is a healthy state physically, mentally, and socially as a whole, not solely free from diseases or disabilities

related to systems, functions, and processes of reproduction. The Government of Indonesia since 1996 has paid serious attention to adolescent reproductive health problems. Modernization, globalization of technology and information as well as various other factors also influence changes in the behavior of adolescent life which then affect their reproductive health. The changes in reproductive health behaviors would impact on the deterioration of the family quality in the future (Fatmawati, 2012).

Reproductive health problems that may be experienced by teenagers include unwanted pregnancy (KTD), abortion, sexually transmitted diseases (STDs), sexual violence, and the problem of limited access to information and health services. Reproductive problems would be affected by physical, mental health, emotions, economic conditions and social welfare of teenagers. The long-term impact also would be affected the family, community, and nation in the end (UNFPA, 2005).

Health Care Services Concern Youth (PKPR) reported the most problem experienced by teenagers who visited the health center in Bandung areas in 2011 was the menstrual disorder $(82 \%)$. Followed by sexually transmitted diseases (8\%), and family planning consultation $(4 \%)$. Other reproductive health problems were dating problems $(2 \%)$, premarital sex (1\%), abortion (1\%), Unwanted Pregnancy (1\%), and HIV / AIDS (1\%).

From the PHC data, the PKPR report also showed that menstrual disorders were the highest ranked (73\%) for adolescent reproductive health issues, followed by contraceptive consultation (15.18\%), sexually transmitted diseases (3.75\%), dating problems (2.4\%), premarital sex (2\%), and HIV / AIDS (1.92\%). The data from the PHC and PKPR program, especially related to PMS, premarital sex, KTD, family planning consultation, and HIV / AIDS showed that teenagers in Bandung have been sexually active. Although the figures are relatively small, the real phenomenon of 
teenage sexual activity may be greater than that recorded by The PHC and PKPR. This data also indicated the need for adolescents to access reproductive health services including family planning (Masunah, 2011).

Knowledge of reproductive health is needed by society, especially the adolescent population. The results of the analysis of the Directorate General of Public Health $\mathrm{MOH}$ and Social Welfare Republic of Indonesia (2010), showed that the condition of reproductive health in Indonesia today was under expectation compare to other ASEAN countries. Indonesia still lags far behind in reproductive health aspects, including adolescent reproductive health (BKKBN, 2012).

Lack of adolescent knowledge about reproductive health would result in adolescents trapped in risky behaviors that impacted their lives, especially their reproductive health (Fatmawati, 2012). Other evidence of adolescent's lack of knowledge about reproductive health can be seen from a lot of questions surrounding reproductive organs, sex behavior during courtship, Sexually Transmitted Infections (IMS), Unwanted Pregnancy (KTD), contraception, sexual harassment, homosexuality to selfconfidence (Ngestiningrum, 2010).

Youth attitudes about reproductive issues (such as premarital sexual intercourse) are still in line with social and religious norms in Indonesia. However, some of them had a tendency to shift values. Sexual behavior from kissing the cheek to a high-risk behavior such as sexual intercourse has been proven by some teenagers in Indonesia. The problem of reproductive behavior among adolescents mentioned above occurs because of some factors including biological factor environmental factors, and a lack of comprehensive (and comprehensive) information about healthy reproduction (Yulfira, 1995).

Indonesian adolescents had limited access to reproductive health information including sexuality as Indonesian society mostly has believed that sexuality is taboo and unfit for open discussion (National Population and Family Planning Agency, 2012). Inaccurate 
reproductive health encouraged teenagers to seek access and conduct their own explorations. Teenagers used the internet media, television, magazines and other forms of mass media as sources to meet their curiosity of reproductive health, it means teenagers developed their attitude and behavior about reproductive health by themselves (BKKBN, 2008).

One of the strategies to improve students' knowledge and attitudes toward reproductive health is reproductive health education. Reproductive health education that early provided for teens would help them to achieve a good attitude and behavior related to reproductive health. It would be better if information on reproductive health provides as early as possible for teens, ideally before puberty and based on age groups (Veronica, 2009).

Reproductive health education in Indonesia is generally done in the form of counseling by institutions outside the school, such as BKKBN and PKBI. Counseling was mostly done at the senior high school level rather than junior high school, whereas the junior high school students' number was larger than the senior high school (Kemenkes RI 2010).

Research showed that adolescents in developing countries are needed for reproductive health education. Adolescents who are in the early stages of secondary school have a risk of sexual intercourse outside of marriage whether intentional or not. The most appropriate time to provide reproductive health education is at the end-grade level of primary school or the junior high school. It would also help teenagers who could not continue their studies to secondary school (WHO, 2011). In addition, WHO emphasized the importance of reproductive health education to young adolescents, the age group of 10 to 14 years. This age is a golden period for a foundation of reproductive health, so it would help them for safer and wiser sexual decisions in their lives (WHO, 2011).

The preliminary study at Madrasah Tsanawiyah Baabussalaam Bandung City found that the number of students of class VIII was 96 studentS and is divided into 3 different classes. The interviews on 5 August 2016 round that Madrasah Tsanawiyah Baabussalaam did not have the Center for Information and Counseling of Reproductive 
Health of Adolescents (PIK-KRR). The school said Madrasah Tsanawiyah Baabussalaam had never received reproductive health education from health workers. Students only get information related to reproduction health from teachers in Biology lessons. The reproductive health information was only the introduction of human reproductive organs.

The interviews with 10 students in grade VIII in Madrasah Tsanawiyah Baabussalaam on August $8^{\text {th }}, 2016$ found that they had never received reproduction health education from health workers. The students said they only get the material of human reproductive organs and puberty from Biology teachers. 7 out of 10 students said they did not know the issues on adolescent reproductive health and how to maintain reproductive organs. 7 of them said that they had a boyfriend, and 4 out of 10 currently have a boyfriend. 9 students said they did not know about STDs and the dangers of STDs.

The interviews related to students' attitudes found that all student support in the adolescent reproductive health education, they said it is important for them to get health education at an early age because they need information about reproductive health so they can prevent problems that often occur in reproductive health. 8 out of 10 students thought that kisses and hugs were normal when dating. While 2 out of 10 students thought that kisses and hugs are inappropriate because they are not muhrim. There were different knowledge and attitudes among students about adolescent reproductive health. This study aimed to examine the influence of health education on the level of knowledge and attitude of adolescents about reproductive health in class VIII Madrasah Tsanawiyah Baabussalaam Bandung.

\section{METHODS}

This study was a quantitative research using pre-experimental approach. This research applied one group pre-post test design. This research characteristic is to reveal the causal effect by involving one group of subjects. The subject group has given questionnaire before and after intervention (Sugiyono, 2015). The population in this study was all students of class VIII (96 students) at Madrasah Tsanawiyah Baabussalaam Bandung City. The sampling technique used in this study was the total 
sampling technique. This study involved 91 students, as 5 students were absent at the research time. This study was conducted from April-November 2016.

\section{RESULTS}

This study found that $37,4 \%$ of respondents had the moderate level of knowledge of the reproduction health before the health education intervention. After health education, the majority of the respondent $(73,6 \%)$ had a good level of knowledge about reproduction health.

\begin{tabular}{lllll}
\hline \multirow{2}{*}{$\begin{array}{l}\text { Categor } \\
\text { y }\end{array}$} & \multicolumn{3}{c}{ Attitude } \\
\cline { 2 - 5 } & Pretest & \multicolumn{2}{c}{ Posttest } \\
\hline Positif & 39 & \% & F & \% \\
Negative & 52 & $57,9 \%$ & 60 & $65,9 \%$ \\
\hline Total & $\mathbf{9 1}$ & $\mathbf{1 0 0 \%}$ & $\mathbf{9 1}$ & $\mathbf{1 0 0 \%}$ \\
\hline
\end{tabular}

Table 1 reveal that before health education $(57.1 \%)$ of respondents had a negative attitude about reproductive health. After health education, the majority of respondents (65.9\%) had a positive attitude toward reproductive health.

Table 2. Respondents' knowledge of reproductive health

\begin{tabular}{llll}
\hline \multirow{2}{*}{ Category } & \multicolumn{2}{c}{ Knowledge } & \multirow{2}{*}{ P- } \\
\cline { 2 - 3 } & \multicolumn{2}{c}{ F (\%) } & Value \\
\cline { 2 - 3 } & \multicolumn{1}{c}{ Pretest } & \multicolumn{1}{c}{ Posttest } & \\
\hline High & 27 & 67 & 0,000 \\
Moderate & $(29,7 \%)$ & $(73,6 \%)$ & \\
Low & 34 & 23 & \\
& $(37,4 \%)$ & $(25,3 \%)$ & \\
& $30(33 \%)$ & $1(1,1 \%)$ & \\
\hline Total & $\mathbf{9 1}$ & $\mathbf{9 1}$ & \\
& $\mathbf{( 1 0 0 \% )}$ & $\mathbf{( 1 0 0 \% )}$ & \\
\hline
\end{tabular}


Table 2 presents the changes in respondents' knowledge before and after the intervention. The result showed there was a significant influence on health education on respondents' knowledge (p-value) 0,000.

Table 3. Respondents' attitude toward reproductive health

\begin{tabular}{|c|c|c|c|}
\hline \multirow[t]{3}{*}{ Category } & \multirow{2}{*}{\multicolumn{2}{|c|}{$\begin{array}{c}\text { Attitude } \\
\text { F (\%) }\end{array}$}} & \multirow{3}{*}{$\begin{array}{c}\text { P- } \\
\text { Value }\end{array}$} \\
\hline & & & \\
\hline & Pretest & Posttest & \\
\hline Positif & $39(42,9 \%)$ & 60 & \multirow[t]{2}{*}{0,000} \\
\hline Negatif & $52(57,1 \%)$ & $\begin{array}{c}(65,9 \%) \\
31 \\
(34,1 \%)\end{array}$ & \\
\hline Total & $91(100 \%)$ & $\begin{array}{c}91 \\
(100 \%)\end{array}$ & \\
\hline
\end{tabular}

Table 3 reveals that there was a significant change in the attitude of respondents before and after the intervention. The result of the statistical test found the value of significance (p-value) is 0.000 . P value $(0.000)<\mathrm{p}$ alpha $(0,05)$ hence Ho is rejected, meaning there was an influence of health education on adolescent attitude level about reproductive health class VIII Madrasah Tsanawiyah Baabussalaam Bandung.

\section{DISCUSSION}

The results of research found that the knowledge of respondents before health education was in moderate level (37.4\%) and the majority of them $(73,6 \%)$ had good knowledge about reproduction health after health education. The results of research inline with a study conducted by Endang Rahayu Fuji Lestary (2014) entitled "The Effect of Reproductive Health Counseling Through Electronic Video Media on the Level of Reproductive Health Knowledge in Junior High School Students 9 Surakarta" showed that the lowest median value of 80 is in pretest results, then after conducted post-test and the median was 97. It can be concluded that the level of pretest score was lower than the post-test. 
Notoatmodjo (2007) stated that knowledge would be influenced by several factors, one of which is the level of education. The level of education can improve one's insight or knowledge. In general, a person with a higher education will have more knowledge than a person with a lower level of education. Knowledge itself is obtained both in formal and informal education. In this case the knowledge of students about reproductive health they get through formal education from the biology lessons.

Health education is a process of transferring health knowledge to individuals or communities (Grouth, 1995). The health education activities include spreading the health message and improving people's confidence so they are not only aware of a health aspect, know and understand but also willing to follow suggestions based on the health education topic (Azwar, 1983 in Susilo 2011).

The health knowledge is also derived from the sense of hearing (ears) and the sense of sight (eye). It influenced by the intensity of attention and perception of each individual. Researchers argued that a reproductive health education conducted by lecture methods and slide media also provided a stimulus to the sense of sight and the sense of hearing of students. This showed from the students' response in the evaluation form of that asked about the adolescent reproductive health (Susilo, 2011).

According to Tana (2004) in Nurfitrianie (2008) cited by Septiana (2014), the various factors had to influence health education including the material media and the subject targets. Supporting media and appropriate strategies would enrich youth knowledge about reproductive health. The health education at school also a method to socialize reproductive health in the adolescent. Teenage reproduction health education should be done continuously.

Respondent's researcher had knowledge about reproductive health because they attended the biology lesson that learns about reproductive organs and stages of human development. Increasing respondents' knowledge after health education intervention may because of respondents' awareness and interest in reproductive health. It also supported by appropriate sources of information which is health workers. 
This study found that before the intervention, 57,1\% had a negative attitude of reproduction health. This finding in line with a research conducted by Kurniawati (2014) with the title "The Effect of Adolescent Reproductive Health Counseling on Knowledge Level and Attitudes of Teens About Sexual Relations Pranikah At SMAN 1 pounding Yogyakarta Year 2014". Kurniawati's (2014) study found that before a counseling intervention the majority of teenagers had a low category of attitude $(90,2 \%)$. Whereas, after the intervention, the percentage changed became $82 \%$.

A person would show a response to a new thing or experience either positive or negative responses. According to Rogger's (1974) theory in Notoadmodjo (2007), the attitude is a response that appears before action. The initial process was someone aware and know the stimulus provided, then the attitude of the subject began to arise against stimulus about reproductive health until finally formed a positive attitude.

The study showed that before health education there were 39 students who had an attitude in the positive category, this may because of before the health education intervention respondents had received information about reproductive health from their teachers. According to Azwar (2007) cited by Asih (2014) argued that one of the factors that affected persons' attitude is the influence an important person for respondents such as the teacher. A person tended to have a conformist attitude or direction with people who are considered important. Meanwhile, there were students with a negative attitude toward reproductive health.

Increasing positive attitude in the experimental group would be influenced by the increase in respondents' knowledge of reproductive health. The changed of attitude from negative into positive may due to respondents had a good understanding of reproductive health after health intervention (Riyanto, 2013). This finding also supported by research conducted by Veronica (2009). She stated that early reproductive health education would help teenagers to achieve a positive attitude of reproductive health. 
There were $34.1 \%$ of respondents had a negative category, it may because of a good attitude is not only required knowledge, but it influenced by other factors such as personal experience, and respondents' background (Azwar, 2007) in Asih (2014). The factors that influence attitudes are someone who is considered important. In this study, the important people were teachers and health workers. Another factor that may affect attitudes is educational institutions. Educational institutions are one place where respondents get correct information about reproductive health.

The result of the research showed that there was a significant difference in the level of the students' knowledge before (pre) and after (post) with p-value 0.000 . The value of pvalue $(0.000) \leq \mathrm{p}$ alpha $(0,05)$, Ho was rejected, it can be concluded that there was a significant difference between knowledge of teens before and after giving reproduction health education.

The results in line with a study conducted by Nydia Rena Benita in 2012 with the title "The Effect of Counseling on the Level of Reproductive Health Knowledge in Teens of Christian Junior High School Students". This was quasi-experimental one group pretestposttest design conducted on 33 respondents using the test paired t-test. The result obtained significance value $(\mathrm{p}<0,01)$. The $\mathrm{p}$-value $(0,01)<\mathrm{p}$ alpha 0,05 indicated that there was a significant difference in knowledge level after the counseling. According to Notoadmodjo (2012) reproduction health education interpreted as an action to influence others such as individuals, groups and even society. Reproductive health education would also produce meaningful improvement in knowledge, attitude, and behavior.

Knowledge is the result of knowing and this happens after the person does the sensing of a particular object. Sensing occurs through the five senses of the human senses of sight, hearing, smell, taste, and touch. Most of the human knowledge is obtained through the eyes and ears. Health education is transferring information to the respondents, then sensing the information, the information has increased, and finally the goof knowledge of students about reproductive health (Notoadmodjo, 2003) in (Wawan and Dewi, 2010). 
According to the researcher's opinion, the level of knowledge is influenced by several other factors such as educational level factors, experiences, and information. Students at in the Madrasah Tsanawiyah Baabussalaam had a moderate level of knowledge due to lack of visits and the implementation of health education periodically from teachers and health workers. During the research process, the role of nurses as educators and facilitators is needed in increasing awareness and knowledge of adolescents in reproductive health. The role of the nurse as a health worker has an important role to provide information to the adolescent about reproductive health so adolescent has a good knowledge in preventing reproduction health.

The result of this study revealed that there was a significant change in the attitude of respondents before and after reproduction health education. The statistical test found (pvalue) is 0.000 . The $p$-value $(0,000) \leq p$ alpha $(0,05)$ means Ho was rejected or there was a significant difference between the attitude of adolescence before and after the reproduction health education.

The results of this study indicated that respondents received health education, and they understood the content of the information. The changes in attitude affected respondents' concern about reproductive health. This finding in agreement with Fauziah's (2015) study with the title "The Influence of Generation Planning to Knowledge Level and Attitude of Reproductive Health In Grade VIII Students At SMPN 1 Kokap Kulon Progo. This pre-experimental with one group pretest-posttest design method conducted on 60 respondents. The data were analyzed using Paired t-test, there was a significance value of students' attitude ( $\mathrm{p}<0,001)$. The $\mathrm{P}$ value was $(0.001)<\mathrm{p}$ alpha 0,05 . It indicated there was a significant influence of counseling on reproductive health attitude in a student. Factors that influence attitudes include personal experiences, an important person, cultural influences, mass media, educational institutions and religious institutions, and emotional factors (Wawan and Dewi, 2010).

This changes in adolescent attitudes revealed that the interventions in this study were able to influence feelings, thinking and predisposition of adolescent actions about reproductive health. Teenagers who have a positive attitude toward reproductive health 
should be maintained and would be reflected in their behavior. On the other hand, adolescents who had a negative attitude toward reproductive health should be supported and facilitated by teachers or health professionals, so reproductive health problems can be anticipated by adolescent and family. Negative attitudes are a problem that may be affected by adolescent actions whether good or poor health behavior. Adolescents need to be aware of the importance of maintaining reproductive health, responsible for themselves, and the environment. Reproductive health education is expected as a routine program for health professionals to adolescents.

\section{CONCLUSION}

It can be concluded that respondents' knowledge had a significantly different before and after educational interventions. The majority of respondents had a positive attitude about reproductive health after interventions. There was an important influence on health education on adolescents' knowledge about reproductive health in Class VIII Madrasah Tsanawiyah Baabussalaam Bandung. There was an influence of health education on adolescent attitudes about reproductive health in Class VIII Madrasah Tsanawiyah Baabussalaam Bandung.

Through this research, it is expected that STIK Immanuel institution would provide health education to adolescents by visiting schools that have never received previous reproduction health education. This research is expected that the school would create a program by conducting reproductive health education on a regular basis. The program would help students obtain correct and correct information about reproduction health especially adolescents. Nurses are expected to perform their role as educator and other roles in providing health education for adolescents, especially on adolescent reproduction health. Next, it is expected that this research would be used as a source of data for further researchers who have an interest in adolescent reproductive health and can develop by using other health education methods.

\section{REFERENCES}

Asih, D. A. 2014. Pengaruh Pendidikan Kesehatan Reproduksi Terhadap Pengetahuan Dan Sikap Mahasiswa Di FIK-UMS. Naskah Publikasi. Universitas Muhammadiyah Surakarta. 
Azwar, S. 2007. Penyusunan Skala Psikologi. Yogyakarta: Pustaka Pelajar. 2008. Sikap Manusia Teori dan Pengukurannya. Yogyakarta : Pustaka Pelajar

Badan Kependudukan dan Keluarga Berencana Nasional. 2008. Kurikulum dan Modul Pelatihan Pengolahan Pusat Informasi dan Konseling Kesehatan Reproduksi Remaja (PIK-KRR), cetakan kedua. Jakarta: Badan Koordinasi Keluarga Berencana Nasional.

Badan Kependudukan dan Keluarga Berencana Nasional. 2012. Survei Demografi dan Kesehatan Indonesia. Jakarta: Kementerian Kesehatan RI.

Benita, N. R. 2012. Pengaruh Penyuluhan Terhadap Tingkat Pengetahuan Kesehatan Reproduksi Pada Remaja Siswa SMP Kristen Gergaji. Karya Tulis Ilmiah. Universitas Diponegoro.

Departemen Kesehatan Republik Indonesia, 2005. Pendekatan dan Penanganan pada Remaja Beresiko Tinggi. Diperoleh dari : http:/www.depkes.go.id/index.php?option=news\&task=viewarticle\&sid=1070\&. Itemid=2. Diakses pada 3 Mei 2016

Departemen Kesehatan Republik Indonesia, 2008. Komunikasi, Informasi, Edukasi (KIE) Kesehatan Reproduksi. Jakarta

Diana, T. P., \& Reni, K. 2013. Antara Kebutuhan dan Tabu: Pendidikan Seksualitas dan Kesehatan Reproduksi bagi Remaja di SMA. Universitas Indonesia

Endang, R. F. L. 2014. Pengaruh Penyuluhan Kesehatan Reproduksi Melalui Media Elektronik Video Terhadap Tingkat Pengetahuan Kesehatan Reproduksi Pada Siswa SMP Negeri 9 Surakarta. Naskah Publikasi. Universitas Muhammadiyah Surakarta.

Ekki, D. A. 2013. Hubungan Pengetahuan tentang Kesehatan Reproduksi terhadap Sikap Menghadapi Sindrom Pre-Menstruasi pada Remaja Putri kelas X dan XI MAN 2 Madiun. Universitas Muhammadiyah Surakarta.

Fauziah, A. 2015. Pengaruh Penyuluhan Generasi Berencana Terhadap Tingkat Pengetahuan dan Sikap Kesehatan Reproduksi Pada Siswa Kelas VIII di SMPN I Kokap Kulon Progo. Stikes Aisyiyah Yogyakarta.

Hidayat, A. 2008. Metode Penelitian Keperawatan dan Teknik Analisa Data. Jakarta : Salemba Medika.

Ima, F. 2012. Perbandingan Tingkat Pengetahuan dan Sikap Remaja Yang Mendapat Program DAKU! Dan Yang Tidak Terhadap Kesehatan Reproduksi Remaja Di Kota Singkawang Tahun 2012. Universitas Indonesia.

Kementerian Kesehatan Republik Indonesia. Profil Kesehatan Indonesia 2009. Jakarta: Kementerian Kesehatan R.I.; 2010 
Kumalasari, I., \& Iwan, A. 2012. Kesehatan Reproduksi untuk Mahasiswa Kebidanan dan Keperawatan. Jakarta: Salemba Medika.

Kusmiran, E. 2011. Kesehatan Reproduksi Remaja dan Wanita. Jakarta: Salemba Medika.

Layyin Mahfina, Elfi Yuliani Rohmah \& Retno Widyaningrum. 2009. Remaja dan Kesehatan Reproduksi. Yogyakarta : STAIN Ponorogo.

Masunah, J. (2011). Profil Pendidikan, Kesehatan, Dan Sosial Remaja Kota Bandung: Masalah dan Alternatif Solusinya. LPPM, Universitas Pendidikan Indonesia.

Nasution, I.K. 2007. Stress Pada Remaja. Universitas Sumatera Utara. Medan

Ngestiningrum, A.H. (2010). Perbandingan Antara Pengaruh Layanan Informasi dan Konseling Kelompok Terhadap Sikap Tintang Kesehatan Reproduksi Remaja. Jurnal Penelitian Kesehatan Suara Forikes Volume 1, Nomor 1.

Nisa, dkk. Hubungan Pengetahuan Dengan Sikap Siswa Terhadap Pendidikan Kesehatan Reproduksi Remaja Di SMAN 1 Margahayu. Universitas Padjajaran Bandung. http://jurnal.unpad.ac.id/index.php/ejournal/article/viewFile/609/663

Notoadmojo, S. 2005. Metodologi Penelitian Kesehatan. Jakarta : Rineka Cipta. 2007. Promosi Kesehatan dan Ilmu Perilaku. Jakarta : Rineka Cipta. 2010. Ilmu Perilaku Kesehatan. Jakarta : Rineka Cipta.

Peraturan Pemerintah Republik Indonesia Nomor 61 Tentang Kesehatan Reproduksi. 2014. http://www.kemenpppa.go.id/jdih/peraturan/PP-Nomor-61-Tahun-2014Tentang-KESEHATAN-REPRODUKSI.pdf

Prajati, R.N. 2014. Hubungan Pengetahuan Kesehatan Reproduksi Remaja Putri Dengan Sikap Menghadapi Premenstrual Syndrome Di SMP Mataram Kasihan Bantul Tahun 2014. Naskah Publikasi. Stikes Aisyiyah Yogyakarta. http://opac.unisayogya.ac.id/1226/1/Naskah\%20Publikasi\%20Riski\%20PDF.pdf

Riwidikdo, H. 2013. Statistik Kesehatan Dengan Aplikasi SPSS dalam Prosedur Penelitian. Rahima Press : Yogyakarta

Riyanto, A. 2011. Aplikasi Metodologi Penelitian Kesehatan. Nuha Medika : Yogyakarta

Septiana. 2014. Pengaruh Pendidikan Kesehatan Terhadap Tingkat Pengetahuan Remaja Tentang Kesehatan Reproduksi Di SMP islam Ruhama Ciputat. Skripsi. Universitas Islam Negeri Syarif Hidayatullah Jakarta.

Sugiyono. 2015. Metode Penelitian Kuantitatif Kualitatif Dan R\&D. Bandung : Alfabeta. 
2015. Statistika untuk Penelitian. Bandung : Alfabeta.

Susilo, R. 2011. Pendidikan Kesehatan dalam Keperawatan. Yogyakarta: Nuha Medika.

UNFPA. (2005). Kebijakan dan Strategi Nasional Pembangunan Kesehatan Reproduksi di Indonesia. Diperoleh dari:

http://indonesia.unfpa.org/application/assets/publications/Kebijakan_Strategi_N asional_Kesehatan_Reproduksi_di_Indonesia.pdf. Diakses pada 5 Mei 2016

Veronica, J. 2009. Pengaruh Metode Simulasi Terhadap Pengetahuan Dan Sikap Guru Tentang Pendidikan Kesehatan Reproduksi Remaja Di Sekolah Menengah Umum Dan Sekolah Menengah Kejuruan Swasta Pencawan Medan Tahun 2009. Tesis. Universitas Sumatera Utara.

Wawan A, Dewi M. 2010. Teori dan Pengukuran Pengetahuan, Sikap, dan Perilaku Manusia. Yogyakart: Nuha Medika.

World Health Organization. The sexual and reproductive health of younger adolescents: research issues in developing countries: background paper for a consultation [homepage on the internet]. c2011. [cited 2016 May 6]. Available from: http://whqlibdoc.who.int/publications/2011/9789241501552_eng.pdf

World Health Organization. Adolescent pregnancy: issues in adolescent health and development [homepage on the internet]. c2004. [cited 2016 May 6]. Available from:

http://www.who.int/child_adolescent_health/documents/9241593784/en/.

Yulfira, M. 1995. Pengetahuan, Sikap dan Perilaku Remaja Tentang Kesehatan Reproduksi. Artikel. Media Litbangkes Vol. Vno. 02/1995. Puslit Ekologi Kesehatan. 